\title{
Peran Pemangku Kepentingan Dalam Pembentukan Komunitas Guna Mencapai Ketahanan Sosial Ekonomi Masyarakat
}

\author{
Irine Kusumatantya ${ }^{1}$ \\ PT Bank Negara Indonesia \\ Jakarta Pusat, Indonesia
}

\begin{abstract}
Abstrak: Perubahan iklim telah menjadi masalah global yang mempengaruhi berbagai aspek kehidupan, seperti kenaikan muka air laut yang menyebabkan banjir dan rob. Pengukuran upaya adaptasi dibutuhkan untuk melewati masalah ini. Hal tersebut akan lebih efisien dan efektif jika pengukuran adaptasi dilakukan secara komunal melalui pengembangan masyarakat. Meski demikian, akses dan sumberdaya yang terbatas membuat masyarakat sulit untuk beradaptasi. Oleh sebab itu, intervensi dari stakeholder lain dibutuhkan untuk menciptakan akses dan untuk mendorong masyarakat dalam pengembangannya. Tidak seperti pada negara maju, partisipasi masyarakat di negara berkembang masih butuh untuk dikendalikan atau didorong oleh intervensi sebagian stakeholder. Setiap stakeholder memiliki tugas, fungsi, dan tanggung jawab yang berbeda sehingga mereka dapat melengkapi satu sama lain. Mereka yang terlibat dalam pengembangan masyarakat berasal dari tiga sektor, yaitu pemerintah, LSM, masyarakat itu sendiri. Dalam menjalankan perannya, para stakeholder bisa jadi tidak bekerja sebagaimana mestinya. Disfungsi peran akan memberi efek negatif pada keberlanjutan komunitas yang terbentuk. Salah satu contohnya adalah pembentukan kelompok tabungan perumahan di Kecamatan Panjang Baru, Pekalongan. Pada prosesnya, kesalahan peran terjadi. Hal tersebut menyebabkan pengembangan masyarakat yang stagnan dan melemahkan ketahanan sosial-ekonomi dari masyarakat yang sudah dibangun melalui pengembangan kelompok tabungan perumahan tersebut.
\end{abstract}

Kata Kunci: disfungsi peran, ketahanan, masyarakat, pemangku kepentingan

\begin{abstract}
Climate change has become one of the global issues which affects various aspects of life, such as a rise in sea levels that results in flood and tidal flood. Adaptation measures need to be done in order to overcome the susceptibilities. It will be more efficicent and effective if the adaptation measures are conducted communally through community development. However, the limited access and resources make people difficult to adapt. Therefore, the intervention of other stakeholders is needed in order to create access and to mobilize society in the community development. Unlike developed countries, society participation in developing countries still needs to be mobilized through the intervention of some stakeholders. Every stakeholder has different task, function, and responsibility so that they can complete each other. The stakeholders which are involved in community development come from three sectors, that are government, non-governmental institutions, and society in the community itself. In doing their role, the stakeholders may not work properly. The role dysfunction will have negative effects on the sustainability of the formed community. One of the examples is the establishment of housing saving group in Panjang
\end{abstract}

\footnotetext{
${ }^{1}$ Korespondensi Penulis: PT Bank Negara Indonesia, Jakarta Pusat, Indonesia

Email: irinekusumatantya@yahoo.com
} 
Baru district, Pekalongan. In its process, the role dysfunction occured. It results in the stagnant community development which weakens socio-economic resilience of the society built through the development of that housing saving group.

Keywords: Community, Resilience, Role Dysfunction, Stakeholders

\section{Pendahuluan}

Perubahan iklim merupakan fenomena global yang disebabkan oleh aktivitas manusia seperti konsumsi energi, industri, transportasi, dan land cover change. Salah satu dampak perubahan iklim global yang signifikan terjadi adalah banjir dan rob di beberapa wilayah. Dampak perubahan iklim tersebut akan dirasakan secara langsung, terutama oleh masyarakat pesisir yang rentan terhadap perubahan. Kerentanan-kerentanan fisiologis wilayah pesisir makin diperparah dengan kondisi struktural masyarakat pesisir yang sebagian besar merupakan masyarakat miskin yang sebagian besar tidak mempunyai kemampuan adaptasi secara optimal, salah satunya karena keterbatasan kualitas sumber daya manusianya.

Tindakan adaptasi diperlukan untuk mengatasi kerentanan yang dihadapi oleh masyarakat pesisir khususnya. Yang pada akhirnya upaya adaptasi tersebut semata-mata untuk mencapai ketahanan masyarakatnya. Ketahanan dijelaskan oleh Wayman (2002), merupakan fenomena yang kompleks yang memungkinkan seseorang untuk dapat berhasil meskipun berada pada kondisi yang merugikan dan kurang membawa manfaat. Ketahanan masyarakat, baik secara sosial maupun ekonomi, dapat dicapai dengan mengoptimalkan penanggulangan dan mekanisme adaptif dalam menghadapi dampak perubahan iklim global seperti banjir dan rob. Pengoptimalan kapasitas adaptasi oleh masyarakat maupun pemangku kepentingan lokal dapat mengurangi kerusakan, memanfaatkan kesempatan dan mengatasi konsekuensi perubahan iklim yang berlangsung lama dan mengacaukan sistem kehidupan manusia.

Kapasitas adaptasi yang dimiliki antara individu dan komunitas tentunya berbeda. Hal tersebut dapat mempengaruhi tindakan adaptasi yang akan dilakukan dan dampaknya pada kehidupan masyarakat luas di masa mendatang. Menurut Fajber (2009), perbedaan kapasitas adaptasi antara individu dan kelompok tergantung pada akses terhadap sumber daya, jaringan sosial, pendidikan, teknologi, dan akses pembangunan lainnya. Adaptasi yang dilakukan secara individu hanya akan mengatasi masalah individu tersebut. Dampaknya pun tidak dapat dirasakan bagi peningkatan kualitas kehidupan masyarakat secara luas. Berbeda halnya jika upaya adaptasi dilakukan oleh komunitas secara berkelompok. Skala ukuran komunitas yang lebih besar daripada individu menjadi salah satu nilai tambah, dengan komunitas dapat dilakukan usaha adaptasi yang lebih efektif dan efisien. Selain itu juga, adanya komunitas dapat saling melengkapi kekurangan antar individu terhadap akses pembangunan

Komunitas dirasa sebagai subyek yang tepat dalam melakukan tindakan adaptasi karena potensi-potensi yang dimiliki komunitas itu sendiri. Komunitas dilibatkan dalam adaptasi, karena masyarakat merupakan kelompok rentan dan paling mengetahui tantangan lokal. Selain itu, fokus perhatian yang memandang komunitas sebagai suatu kesatuan dapat meningkatkan kondisi kehidupan masyarakat. Kesatuan komunitas cenderung mengandalkan pemanfaatan dan pendayagunaan sumberdaya yang ada untuk merealisasikan tujuan (Soetomo, 2006:86). Kemampuan komunitas dalam memobilisasi sumberdaya lokal dapat menjadi kunci untuk meningkatkan kondisi kehidupan masyarakat yang rentan banjir dan rob. 
Upaya pengembangan komunitas kental adanya unsur partisipasi masyarakat. Berbeda dengan negara maju, partisipasi masyarakat di negara berkembang masih harus dimobilisasi melalui campur tangan pemerintah dalam mengupayakan kerjasama. Oleh karena itu, peran pemangku kepentingan sangatlah penting dalam pembentukan komunitas guna mengurangi kerentanan masyarakat akibat banjir dan rob. Pemangku kepentingan dapat berperaan sebagai inisiator dan koordinator pembentukan komunitas, hingga melakukan pembinaan terhadap komunitas yang telah terbentuk. Pemangku kepentingan berasal dari berbagai lapisan, yaitu pemerintah kota, pemerintah lokal, lembaga non pemerintah dan masyarakat itu sendiri.

Pemangku kepentingan merupakan aktor-aktor kunci dalam pengembangan komunitas. Mereka dapat terlibat secara langsung maupun tidak langsung. Keterlibatan pemangku kepentingan tersebut akan membawa dampak bagi keberlangsungan komunitas (Race dan Millar, 2006). Pemangku kepentingan yang terlibat juga akan merasakan dampak dan manfaat yang timbul (Gonsalves et al, 2005).

Setiap pemangku kepentingan mempunyai berbagai kemungkinan dapat melalukan disfungsi peran. Disfungsi peran tersebut tentunya akan membawa dampak negatif bagi keberlanjutan komunitas yang terbentuk. Hal tersebut dikarenakan, pemangku kepentingan yang berkecimpung secara langsung dalam upaya pembentukan dan pengembangan komunitas tidak melakukan peran yang semestinya. Padahal peran masing-masing pemangku kepentingan secara langsung maupun tidak langsung telah ter-plotting sesuai dengan tugas dan fungsinya yang akan menjadi sebuah tanggung jawab. Akibatnya, disfungsi peran tersebut dapat menjadi hambatan dalam pengembangan komunitas.

Yang menarik untuk dikaji adalah bagaimana peran pemangku kepentingan dalam pembentukan komunitas guna mencapai ketahanan sosial ekonomi masyarakat dengan studi kasus pembentukan kelompok tabungan perumahan di Kelurahan Panjang Baru, Kota Pekalongan. Siapa sajakah pemangku kepentingan yang terlibat. Apakah peran pemangku kepentingan tersebut mempengaruhi keberlangsungan kelompok dan bagaimana implikasinya terhadap ketahanan sosial ekonomi yang sedang berusaha untuk dibangun.

\section{Pemangku Kepentingan dalam Pembentukan Komunitas}

Pemangku kepentingan dapat berupa organisasi, komunitas, kelompok sosial ekonomi, pemerintah, atau lembaga yang berasal dari berbagai dimensi pada setiap tingkat golongan masyarakat (Iqbal, 2007:90). Setiap subyek tersebut mempunyai potensi, sumberdaya dan kebutuhan masing-masing. Keterlibatannya dalam pelaksanaan suatu aktivitas (baik terkait pembangunan maupun tidak) disesuaikan dengan kapasitas yang dimiliki. Penting untuk diingat bahwa kebutuhan masing-masing pemangku kepentingan harus terwakili dalam proses pengambilan keputusan. Hal tersebut dikarenakan akan mempengaruhi tingkat kepuasan dari setiap pemangku kepentingan terhadap hasil kegiatan yang sedang dilaksanakan.

Pemangku kepentingan dapat diklasifikasikan menjadi tiga kelompok. Kelompok tersebut adalah pemangku kepentingan utama, penunjang, dan kunci (Crosby, 1992). Pemangku kepentingan utama merupakan pemangku kepentingan yang menerima dampak positif dan negatif dari suatu kegiatan. Pemangku kepentingan penunjang merupakan perantara yang membantu proses penyampaian kegiatan. Pemangku kepentingan kunci yakni yang mempunyai pengaruh kuat atau penting terkait dengan masalah, kebutuhan, dan perhatian terhadap kelancaran kegiatan (Iqbal, 2007:90). Pendapat lain mengatakan bahwa, pemangku kepentingan dapat dibagi menjadi pemangku kepentingan sektor swasta, sektor publik dan masyarakat sipil (Start dan Hovland, 2010). Berdasarkan pengertian mengenai pemangku kepentingan tersebut, maka dua klasifikasi pemangku kepentingan tersebut sama saja, yaitu pemangku kepentingan utama sama dengan 
masyarakat sipil, sektor swasta sama dengan penunjang, dan sektor publik sama dengan pemangku kepentingan kunci.

Berdasarkan klasifikasi tersebut, pemangku kepentingan terkait hubungan kerjasama dalam membangun ketahanan dapat diidentifikasi dan digolongkan sebagai berikut:

Tabel 1. Klasifikasi Pemangku Kepentingan dalam Membangun Ketahanan Masyarakat

\begin{tabular}{l|l|l}
\hline \multicolumn{2}{c}{ Pemangku Kepentingan } \\
\hline \multicolumn{1}{c}{ Utama } & \multicolumn{1}{|c}{ Penunjang } & \multicolumn{1}{c}{ Kunci } \\
\hline - Masyarakat Pesisir & $\bullet$ LSM & $\bullet$ Pemerintah (Pusat, Kota dan Lokal) \\
- Komunitas & $\bullet$ Pihak Swasta & $\bullet$ Lembaga Kemasyarakatan Lokal \\
& $\bullet$ Lembaga Finansial & $\bullet$ Badan Internasional (Bank Dunia, UN) \\
& $\bullet$ Lembaga Donor & \\
\hline
\end{tabular}

Sumber: Penyusun dan kumpulan dari berbagai sumber, 2011

\section{Peran Pemangku Kepentingan dalam Pembentukan Komunitas Masyarakat}

Masing-masing pemangku kepentingan yang terlibat dalam pembentukan komunitas mempunyai karakteristik yang berbeda. Karakteristik tersebut meliputi tingkat kepentingan dan pengaruh masing-masing pemangku kepentingan tersebut. Ada pemangku kepentingan yang memiliki pengaruh besar, tapi tidak memiliki kepentingan yang cukup besar dalam pelaksanaan kerjasama pengembangan komunitas. Ada pula pemangku kepentingan yang tidak mempunyai pengaruh besar, tapi memiliki peran penting dalam menginisiasi dan melaksanakan kegiatan-kegiatan dalam kerjasama tersebut. Matriks pemangku kepentingan berfungsi untuk mem-plotting peran pemangku kepentingan dalam upaya pengembangan komunitas.

\begin{tabular}{|c|c|c|c|c|c|}
\hline & & $\begin{array}{c}\text { Tidak } \\
\text { ada }\end{array}$ & $\begin{array}{c}\text { Sedikit/tidak } \\
\text { penting }\end{array}$ & $\begin{array}{l}\text { Cukup } \\
\text { penting }\end{array}$ & $\begin{array}{r}\text { Sangat } \\
\text { penting }\end{array}$ \\
\hline \multirow{4}{*}{ 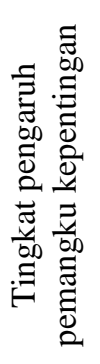 } & Sangat berpengaruh & & \multirow{2}{*}{$\mathrm{C}$} & \multirow{2}{*}{\multicolumn{2}{|c|}{ A }} \\
\hline & Cukup berpengaruh & & & & \\
\hline & $\begin{array}{l}\text { Sedikit/tidak } \\
\text { berpengaruh }\end{array}$ & & \multirow{2}{*}{$\mathrm{D}$} & \multirow{2}{*}{\multicolumn{2}{|c|}{ B }} \\
\hline & Tidak ada & & & & \\
\hline
\end{tabular}

Sumber: Department of Sustainability and Environtment Victoria, 2011

\section{Gambar 1. Matriks Pemangku Kepentingan}

Peran pemangku kepentingan biasanya berupa intervensi awal sebagai penggerak masyarakat agar ikut berpartisipasi dalam upaya pengembangan komunitas membangun ketahanannya. Intervensi dari luar komunitas dapat mendorong tumbuhnya perubahan dan pembaharuan dalam pengembangan komunitas. Namun, intervensi dari pemangku 
kepentingan juga dapat memberikan dampak negatif. Hal tersebut tergantung pada bagaimana intervensi yang dilakukan dalam komunitas tersebut. Seperti yang dikatakan Soetomo (2006:138) Intervensi dikatakan dapat menimbulkan ketergantungan apabila masyarakat yang tadinya statis menjadi tergerak untuk melakukan perubahan dan pembaharuan setelah memperoleh intervensi dari luar, tetapi kemudian kembali menjadi statis setelah intervensi dihentikan.

Peran pemangku kepentingan, seperti pemerintah dan swasta hanya sebagai pendamping, pembina, dan pengawas berjalannya kegiatan dalam komunitas tersebut. Batasan peran perlu ditegaskan sehingga masyarakat dalam suatu komunitas tidak terusmenerus bergantung pada bantuan pemangku kepentingan lain. Peran pemangku kepentingan diperlukan hingga terbentuk komunitas yang kokoh dan madani, dengan demikian komunitas telah dapat mengaktualisasikan potensi yang dimiliki dan mempunyai akses terhadap pembangunan. Dengan demikian, adanya peran serta pemangku kepentingan tetap diperlukan dengan syarat peran atau intervensi tersebut dilakukan secara proporsional.

Tabel 2. Peran Pemangku Kepentingan dalam Pengembangan Komunitas

\begin{tabular}{|c|c|c|c|}
\hline Peran & Pemerintah & Masyarakat & Swasta \\
\hline Regulasi & - Kebijakan dan strategi & & \\
\hline Pemberdayaan & $\begin{array}{l}\text { - Sosialisasi program- } \\
\text { program }\end{array}$ & $\begin{array}{l}\text { - Turut serta (partisipasi) } \\
\text { dalam kegiatan } \\
\text { - Sosialisai dan } \\
\text { penularan informasi }\end{array}$ & $\begin{array}{l}\text { - Sosialisasi manajemen } \\
\text { kegiatan pengembangn } \\
\text { komunitas }\end{array}$ \\
\hline Pendampingan & - Pelatihan dan pembinaan & $\begin{array}{l}\text { - Penjaringan anggota } \\
\text { komunitas }\end{array}$ & $\begin{array}{l}\text { - Penyediaan tenaga ahli } \\
\text { dan fasilitator }\end{array}$ \\
\hline Penguatan & $\begin{array}{l}\text { - Pembangunan kerjasama } \\
\text { dengan pemangku } \\
\text { kepentingan lain } \\
\text { - memfasilitasi kebutuhan } \\
\text { dasar komunitas } \\
\text { - Penyuluhan }\end{array}$ & $\begin{array}{l}\text { - Kerjasama dengan } \\
\text { catur pilar dan pihak } \\
\text { luar } \\
\text { - Penyusunan rencana } \\
\text { kegiatan, aturan dan } \\
\text { norma } \\
\text { - Pelaksanaa kegiatan }\end{array}$ & $\begin{array}{l}\text { - Penjalinan kerjasama } \\
\text { dengan pemerintah dan } \\
\text { masyarakat } \\
\text { - Bantuan modal } \\
\text { (finansial) }\end{array}$ \\
\hline
\end{tabular}

Sumber: Modifikasi dari Chifos, 2007 dan Meneses et al, 2005 dalam Wea, 2009

\section{Metode Penelitian}

Metode yang digunakan dalam penelitian ini adalah deskriptif kualitatif, melalui survei primer dengan teknik wawancara. Selain itu dilakukan pula kajian melalui telaah literatur terkait peran pemangku kepentingan dalam pengembangan komunitas.

\section{Pembahasan}

Pemangku kepentingan yang terlibat dalam kelompok tabungan perumahan sebagai wujud nyata terjalinnya kerjasama, berasal dari berbagai latar belakang yang berbeda. Dari sekian banyak pemangku kepentingan yang terlibat mulai dari proses sosialisasi hingga pembinaan kelompok yang telah terbentuk dapat diklasifikasikan menjadi tiga kelompok pemangku kepentingan. Menurut Crosby (1992) kelompok tersebut adalah pemangku kepentingan utama, penunjang, dan kunci. Jika ditinjau kembali mulai dari proses pembentukan kelompok tabungan perumahan sudah dapat diidentifikasi pemangku kepentingan yang terlibat, antara lain adalah: Bapermas KB, Catur Pilar (Kelurahan, BKM, 
LPM, PKK), masyarakat, dinas pemerintah lain sebagai pendukung (DPPK, KLH, dll), dan lembaga keuangan (BRI, Bank Sahabat). Pemangku kepentingan yang telah teridentifikasi tersebut dapat diklasifikasikan sebagai berikut.

Tabel 3. Klasifikasi Pemangku Kepentingan dalam Kerjasama Membangun Ketahanan Masyarakat

\begin{tabular}{|c|c|c|}
\hline \multicolumn{3}{|c|}{ Pemangku Kepentingan } \\
\hline Utama & Penunjang & Kunci \\
\hline - Masyarakat (Anggota Kelompok) & $\begin{array}{ll} & \text { BKM } \\
\text { - } & \text { LPM } \\
\text { - } & \text { Dinas Pendukung (DPPK, KLH, dll) } \\
\text { - } & \text { Ormas Layur } \\
\text { - } & \text { Lembaga keuangan (BRI, Bank Sahabat) }\end{array}$ & $\begin{array}{ll}\text { - } & \text { Bapermas KB } \\
\text { - } & \text { PKK } \\
\text { - } & \text { Kelurahan } \\
\text { - } & \text { RT dan RW }\end{array}$ \\
\hline
\end{tabular}

Sumber: Analisis Penyusun, 2011 dan Crosby, 1992

\section{Pembentukan Kelompok Tabungan Perumahan}

Pemangku kepentingan utama, kunci dan penunjang tersebut saling bekerjasama dalam proses pembentukan dan pengembangan kelompok. Dalam prosesnya, beberapa pemangku kepentingan mempunyai peran yang menonjol dan berkontribusi dalam keberhasilan pembentukan kelompok.

Kelompok tabungan perumahan dibentuk dengan tujuan untuk menggerakkan masyarakat yang menerima bantuan pemugaran rumah agar bisa mandiri untuk meneruskan penyempurnaan kualitas rumahnya, sehingga dapat menjadi rumah dengan kualitas layak huni tanpa harus menggantungkan bantuan dari pemerintah. Kegiatan tabungan perumahan tersebut merupakan inovasi dari pendekatan Tri Bina, khususnya Bina Lingkungan.

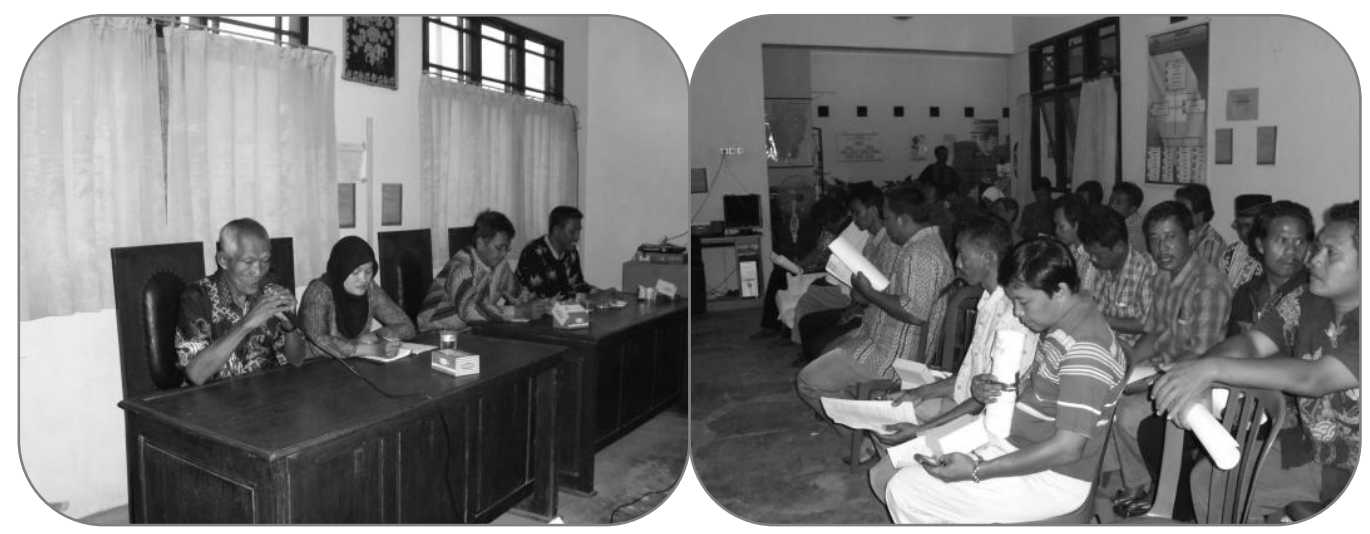

Sumber: Dokumentasi BKM Panjang Baru, 2010

Gambar 2. Pertemuan Sosialisasi Program Bedah Rumah Menpera dan Tabungan Masyarakat

Pembentukan kelompok tabungan perumahan dimulai dari proses sosialisasi yang dilakukan pada awal tahun 2010. Kegiatan sosialisasi merupakan poin penting dalam pelaksanaan program tabungan perumahan ini. Sosialisasi berfungsi sebagai proses inisiasi 
kegiatan tabungan perumahan kepada masyarakat. Dalam sosialisasi juga terjadi proses pertukaran informasi mengenai pengenalan tujuan dan sasaran kegiatan tabungan perumahan ini. Kegiatan sosialisasi ini merupakan proses transfer informasi awal antar pemangku kepentingan melalui penjelasan dan dialog terbuka.

Bapermas memiliki peran penting untuk menginisiasi masyarakat dan pemangku kepentingan lain untuk lebih memahami dan melaksanakan program tabungan perumahan ini. Dinas-dinas pemerintah berperan dalam dukungan teknis pelaksanaan kegiatan tabungan perumahan ini. Catur Pilar berfungsi sebagai pengawas dan pemerhati yang tidak berkecimpung secara langsung. Adapun sasaran utama dalam proses pertukaran informasi ini adalah masyarakat yang diwakili oleh ketua RT dan RW setempat. Perwakilan tersebutlah yang merupakan agen pentransfer informasi ke masyarakat yang lebih luas.

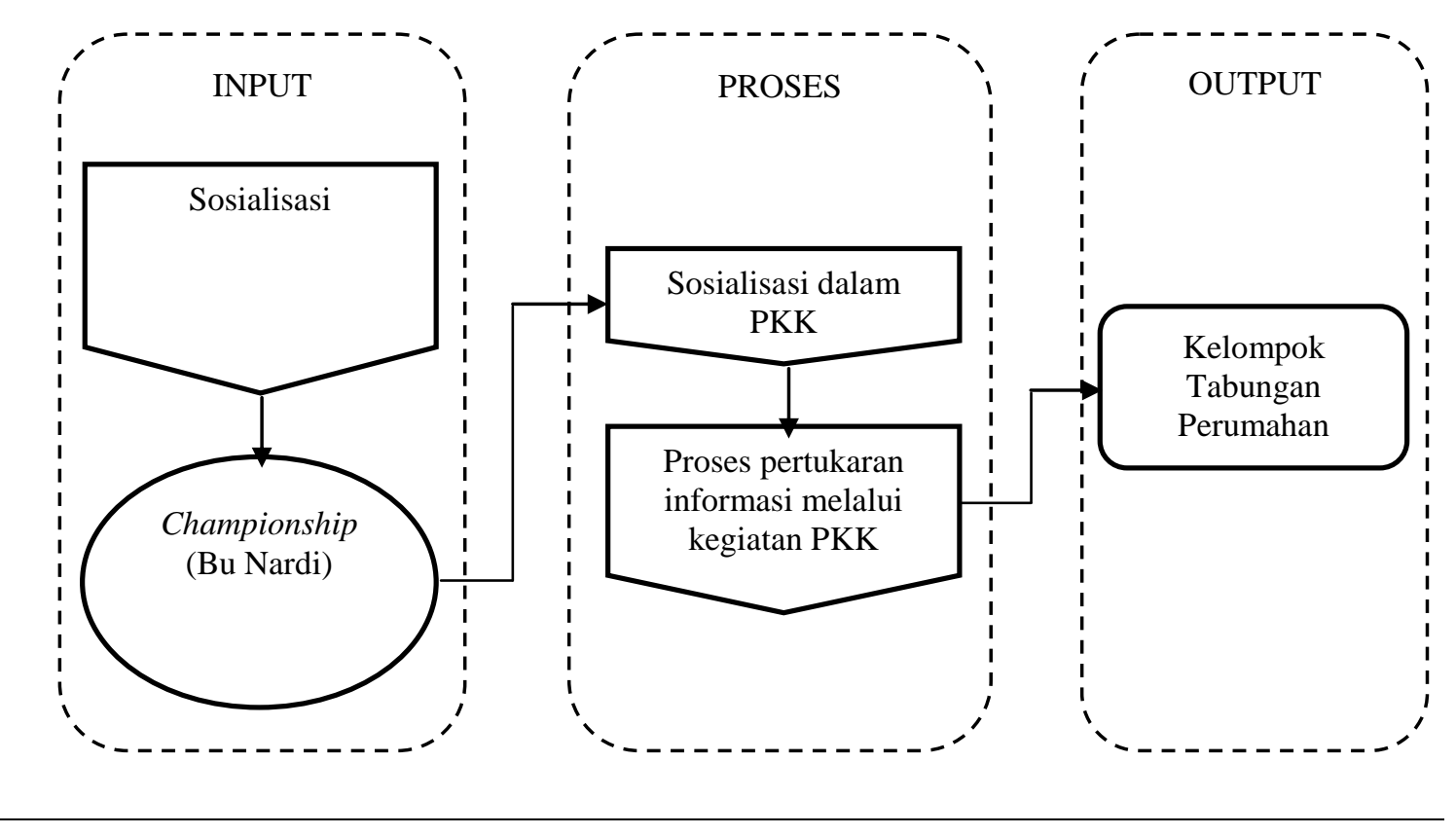

Gambar 3. Proses Pembentukan Kelompok Kondisi Riil

Namun yang terjadi di lapangan, proses pembentukan kelompok sesuai rencana tersebut tidak berhasil dilakukan. Proses pertukaran dan transfer informasi hasil sosialisasi kegiatan tabungan perumahan tidak tersampaikan hingga ketingkat akar rumput. Melihat kondisi tersebut, Bu Nardi yang pada saat itu adalah istri dari ketua RW 7 turut prihatin dan memiliki inisiatif untuk menggerakkan kembali kegiatan tabungan perumahan ini. Sebagai istri ketua RW, tentunya Bu Nardi sangat paham akan tujuan, sasaran dan manfaat dari kegiatan tabungan perumahan ini. Sebagai agen penggerak, Bu Nardi membangkitkan kembali kegiatan tabungan perumahan ini melalui forum PKK. Proses pertukaran informasi juga dilakukan melalui kegiatan PKK. 


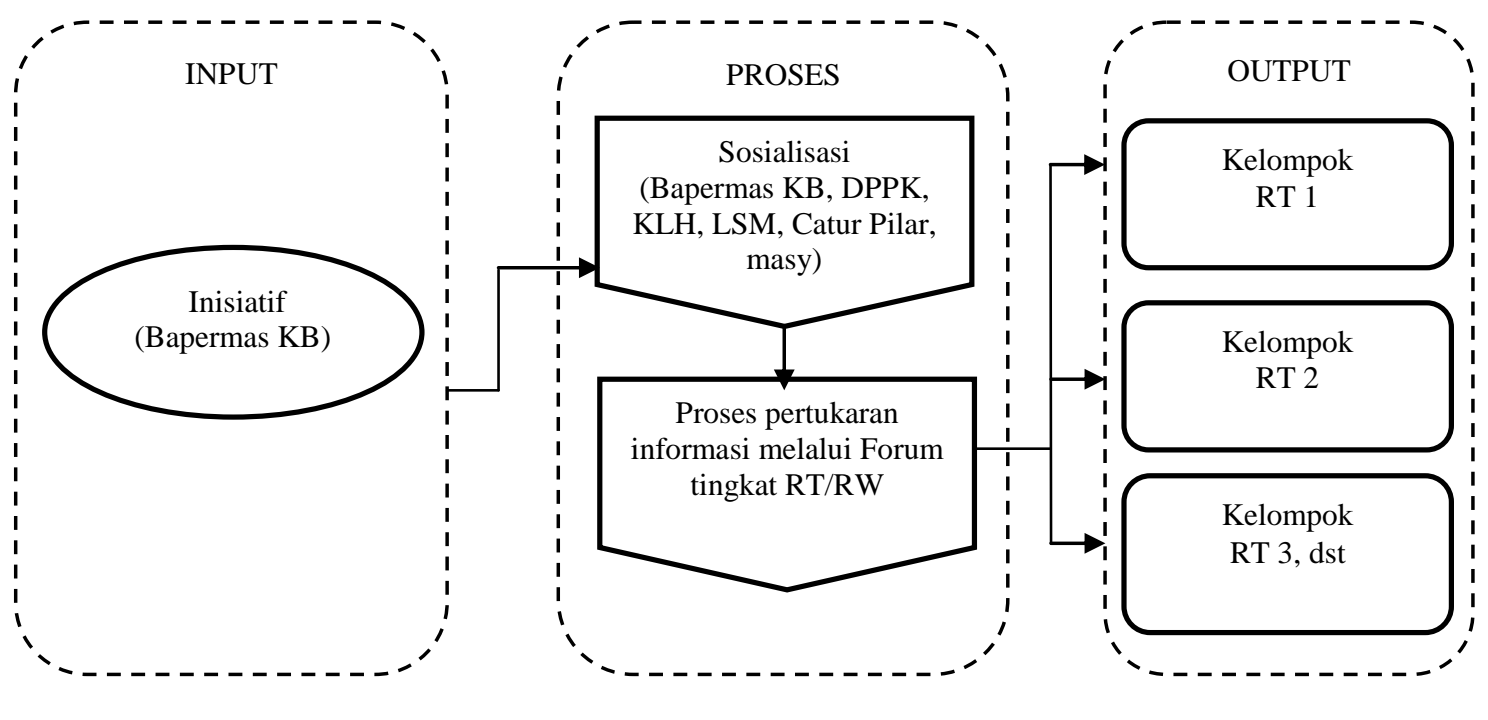

Gambar 4. Proses Pembentukan Kelompok Rencana Bapermas

Terbentuknya kelompok tabungan perumahan tersebut tentunya menciptakan suatu mekanisme kerjasama antar pemangku kepentingan dalam kelompok, sebagai upaya mengembangkan kegiatan kelompok. Masing-masing pemangku kepentingan mempunyai stereotip yang berbeda terhadap mekanisme kerjasama ini. Tidak semuanya memiliki pandangan positif terhadap keberlangsungan kerjasama ini. Hal tersebut tentunya akan memberikan pengaruh terhadap berjalannya kegiatan dalam kelompok. Menurut Walgito (2003), stereotip positif terhadap kerjasama dapat diciptakan melalui pembentukan perilaku masing-masing pemangku kepentingan yang terlibat.

Bapermas dan $\mathrm{Bu}$ Nardi secara tidak langsung melakukan proses pembentukan perilaku dalam internal kelompok. Pembentukan perilaku tersebut dapat meningkatkan motivasi dan partisipasi masyarakat untuk bergabung menjadi anggota kelompok. Berikut merupakan proses pembentukan perilakunya:

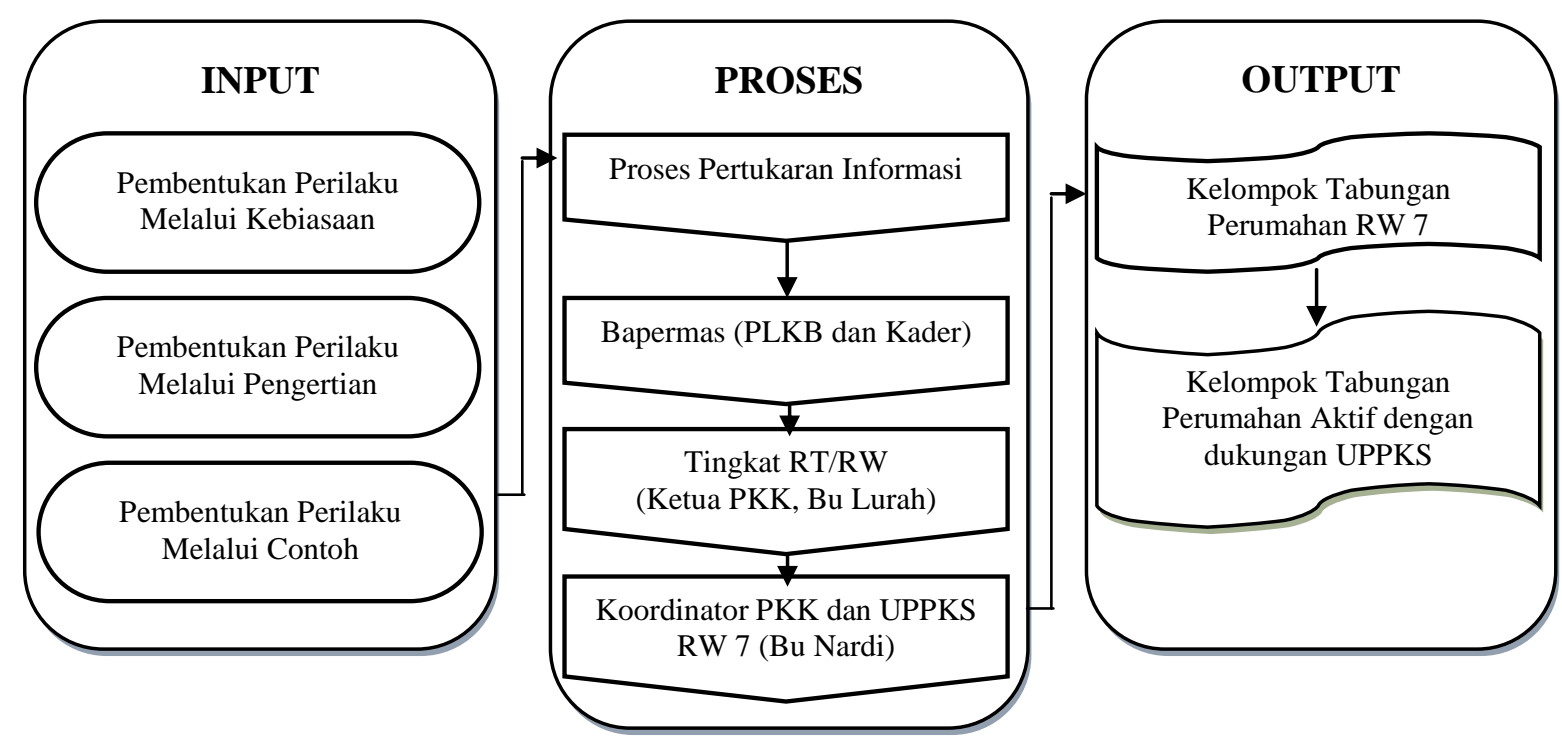

Gambar 5. Proses Pembentukan Perilaku Internal Kelompok 
Terbentuknya kelompok di RW 7 Panjang Baru membuktikan bahwa pemerintah (Bapermas) dapat menginisiasi masyarakat secara kelompok. Proses inisiasi tersebut dapat berhasil dengan adanya keterbukaan masyarakat dalam menerima pengaruh dari pihak luar untuk menginisiasi kerjasama. Dalam proses pembentukan kelompok tersebut, tidak berjalan lancar hanya dengan mengandalkan proses inisiasi dari pemerintah saja, namun dibutuhkan juga agen penjembatan (intermediary agent) dan pentransfer informasi dari pemerintah ke masyarakat. Keberhasilan dalam pembentukan kelompok di RW 7 Panjang Baru juga didukung dengan adanya sikap championship dari Bu Nardi yang berperan sebagai penggerak dan intermediary agent, sekaligus sebagai aktor championship.

Adanya aktor championship tersebut tidak selamanya membawa implikasi positif. Sikap championship tersebut semestinya dapat menjadi teladan dan direplikasi oleh masyarakat anggota kelompok yang lain, sehingga dapat meneruskan upaya pengembangan kerjasama kelompok tabungan perumahan. Namun yang terjadi, adanya peranan aktor championship tersebut malah menimbulkan ketergantungan bagi masyarakat anggota kelompok tabungan perumahan.

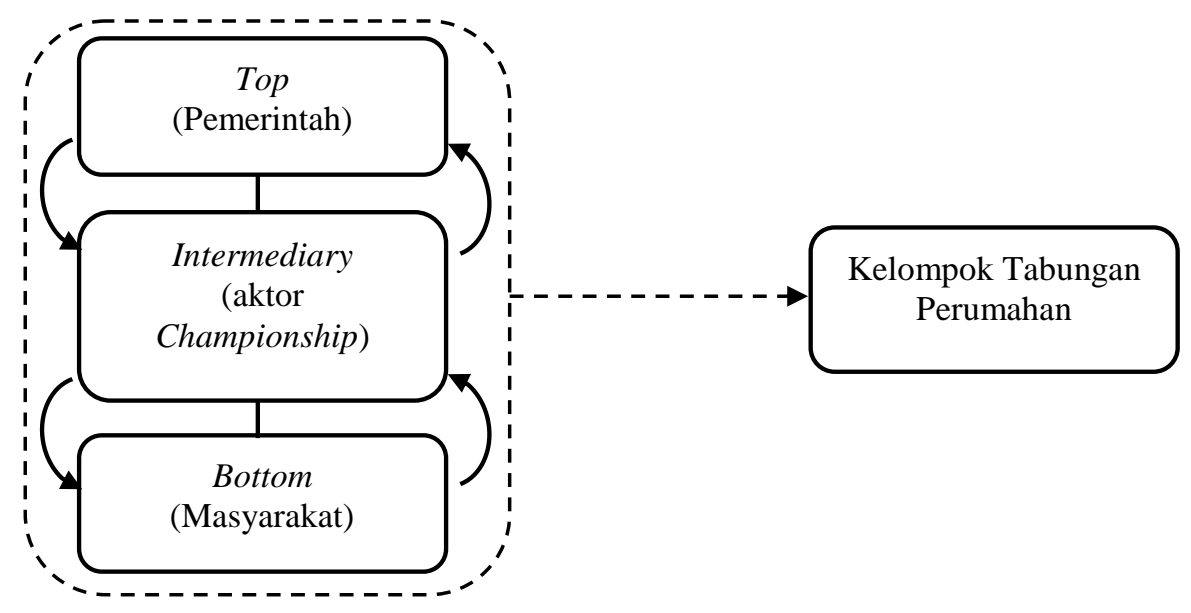

\section{Gambar 6. Intermediary Agent dalam Pembentukan Kelompok}

\section{Peran Pemangku Kepentingan dalam Keberlanjutan Kelompok Tabungan Perumahan}

Pemangku kepentingan yang telah teridentifikasi terlibat dalam pembentukan dan pengembangan kelompok tabungan perumahan mempunyai kepentingan yang berbedabeda dalam berjalannya kerjasama, baik dalam maupun diluar kelompok. Kepentingan tersebut sesuai dengan karakteristik peran dan tanggung jawab masing-masing pemangku kepentingan. Berikut ini adalah kepentingan masing-masing pemangku kepentingan yang terlibat dalam proses pembentukan kelompok tabungan perumahan.

Tabel 4. Peran Pemangku Kepentingan dalam Kerjasama

\begin{tabular}{|l|l|}
\hline Kelompok Pemangku & \multicolumn{1}{c|}{ Kepentingan } \\
\hline Bapermas KB & $\begin{array}{l}\text { Penanggung jawab program tabungan perumahan } \\
\end{array}$ \\
& $\begin{array}{l}\text { - Pelaku inisiasi, sosialisasi, dan pembinaan } \\
\text { perumbuat kebijakan dan peraturan mengenai kelangsungan tabungan }\end{array}$ \\
\hline
\end{tabular}


Lanjutan Tabel 4.

\begin{tabular}{|c|c|}
\hline Kelor & Kepentingan \\
\hline & - Agen kunci dalam pembentukan perilaku dan pendorong terjalinnya kerjasama \\
\hline PKK & $\begin{array}{l}\text { - Forum pertemuan dan pertukaran informasi } \\
\text { - Peluang untuk transfer informasi dan pembentukan perilaku sebagai motivasi } \\
\text { kelompok } \\
\text { - Agen kunci dalam pembentukan perilaku dan pendorong terjalinnya kerjasama }\end{array}$ \\
\hline Kelurahan & $\begin{array}{l}\text { - Lembaga tertinggi skala Kelurahan Panjanga Baru } \\
\text { - Pengawas kelompok tabungan perumahan baik secara langsung maupun tidak } \\
\text { langsung } \\
\text { - Pengayom masyarakat khususnya anggota kelompok tabungan perumahan } \\
\text { - Penjembatan antara aspirasi masyarakat dan pemerintah (Bapermas) }\end{array}$ \\
\hline RT dan RW & $\begin{array}{l}\text { - Kepanjangan tangan dari kelurahan } \\
\text { - Penyalur informasi ke masyarakat luas } \\
\text { - Perwakilan penyalur dan penampung aspirasi masyarakat di tingkat akar } \\
\text { rumput } \\
\text { - Agen kunci dalam pembentukan perilaku dan pendorong terjalinnya kerjasama }\end{array}$ \\
\hline $\begin{array}{l}\text { Masyarakat (Anggota } \\
\text { Kelompok Tabungan } \\
\text { Perumahan) }\end{array}$ & $\begin{array}{l}\text { - Penerima manfaat dan dampak dari kerjasama } \\
\text { - Pengelola dan pelaksana kegiatan tabungan perumahan } \\
\text { - Agen kunci dalam pembentukan perilaku dan pendorong terjalinnya kerjasama }\end{array}$ \\
\hline BKM & $\begin{array}{l}\text { - Pengelola kegiatan di bidang sosial, ekonomi, dan lingkungan Kelurahan } \\
\text { Panjang Baru } \\
\text { - Penampung aspirasi masyarakat } \\
\text { - Pelengkap catur pilar dalam kerjasama tabungan perumahan } \\
\text { - Pengawas dan pemerhati kegiatan tabungan perumahan secara tidak langsung }\end{array}$ \\
\hline LPM & $\begin{array}{l}\text { - Pengelola pembangunan fisik wilayah Kelurahan Panjang Baru } \\
\text { - Pelengkap catur pilar dalam kerjasama tabungan perumahan } \\
\text { - Pengawas dan pemerhati kegiatan tabungan perumahan secara tidak langsung }\end{array}$ \\
\hline $\begin{array}{l}\text { Dinas Pendukung (KLH, } \\
\text { Disperindagkop, DPPK, } \\
\text { dll) }\end{array}$ & $\begin{array}{l}\text { - Pendukung pelaksanaan teknis program tabungan perumahan } \\
\text { - Pendamping lapangan dalam implementasi kegiatan sesuai dengan bidangnya } \\
\text { - Mitra kerja Bapermas dalam pelaksanaan program }\end{array}$ \\
\hline $\begin{array}{l}\text { Lembaga keuangan } \\
\text { (BRI, Bank Sahabat) }\end{array}$ & $\begin{array}{l}\text { - Pendukung keberlangsungan kelompok tabungan perumahan dan UPPKS } \\
\text { - Penyedia simpan pinjam bagi masyarakat }\end{array}$ \\
\hline Ormas Layur & $\begin{array}{l}\text { - Penjembatan antara masyarakat dan pemerintah } \\
\text { - Berkecimpung di bidang lingkungan } \\
\text { - Tidak berhubungan dan berperan langsung dalam berjalannya kerjasama } \\
\text { kelompok tabungan perumahan }\end{array}$ \\
\hline
\end{tabular}

Jika dalam mekanisme operasional, kepentingan masing-masing pemangku kepentingan tersebut, Bapermas lah yang memegang peranan kunci bagi keberhasilan dalam kerjasama ini. Selanjutnya pemangku kepentingan yang juga dapat mempengaruhi kerjasama dalam kelompok tabungan perumahan adalah lembaga lokal seperti catur pilar, RT, RW dan masyarakat anggota kelompok itu sendiri. Apabila dilihat dari tingkat kepentingan dan pengaruh terhadap berjalannya kerjasama dalam kelompok, masingmasing pemangku kepentingan dapat dikelompokkan pada matriks berikut ini. 


\begin{tabular}{|c|c|c|c|c|c|}
\hline & & \multicolumn{4}{|c|}{ Tingkat Kepentingan Pemangku Kepentingan (Stakeholder) } \\
\hline & & $\begin{array}{c}\text { Tidak } \\
\text { ada }\end{array}$ & $\begin{array}{l}\text { Sedikit/tidak } \\
\text { penting }\end{array}$ & Cukup penting & Sangat penting \\
\hline \multirow{4}{*}{ 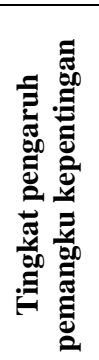 } & $\begin{array}{c}\text { Sangat } \\
\text { berpengaruh }\end{array}$ & \multirow{2}{*}{\multicolumn{2}{|c|}{$\begin{array}{l}\text { C } \\
\text { BKM, Dinas Pendukung (KLH, } \\
\text { Disperindagkop, DPPK, dll) }\end{array}$}} & \multirow{2}{*}{\multicolumn{2}{|c|}{ Bape }} \\
\hline & $\begin{array}{c}\text { Cukup } \\
\text { berpengaruh }\end{array}$ & & & & \\
\hline & $\begin{array}{l}\text { Sedikit/tidak } \\
\text { berpengaruh }\end{array}$ & \multirow{2}{*}{\multicolumn{2}{|c|}{$\begin{array}{l}\text { D } \\
\text { LPM, Ormas Layur, Lembaga } \\
\text { keuangan (BRI, Bank Sahabat) }\end{array}$}} & \multirow{2}{*}{\multicolumn{2}{|c|}{$\begin{array}{l}\text { B } \\
\text { PKK, Kelurahan, RT dan RW, } \\
\text { Masyarakat (Kelompok tabungan } \\
\text { perumahan \& UPPKS Tambak) }\end{array}$}} \\
\hline & Tidak ada & & & & \\
\hline
\end{tabular}

\section{Gambar 7. Matriks Pemangku Kepentingan}

Pemangku kepentingan pada kuadran B, merupakan pemangku kepentingan yang sangat penting tapi dalam proses berjalannya kerjasama, baik internal maupun eksternal kelompok tidak memberikan pengaruh yang cukup signifikan. Pemangku kepentingan tersebut adalah masyarakat, baik ketua RT, RW maupun anggota kelompok tabungan perumahan itu sendiri. Dalam kerjasama ini, masyarakat terkesan hanya dianggap sebagai kelompok sasar dan penerima manfaat saja. Masyarakat kurang aktif mengemukakan aspirasi dalam proses kerjasama ini. Mereka pun kurang berupaya secara mandiri untuk menghidupkan kelompok dan meningkatkan sinergitas kerjasama, baik secara internal maupun eksternal.

Peran pemangku kepentingan di kuadran B perlu untuk dioptimalkan. Masyarakat, baik dari perwakilan RT/RW maupun anggota kelompok tabungan merupakan pemangku kepentingan utama. Yang diharapkan, mereka tidak hanya dianggap penting sebagai sasaran saja. Melainkan dapat juga berperan menjadi pemangku kepentingan yang turut aktif mengusulkan inovasi baru dalam kerjasama, sehingga mereka mempunyai pengaruh dan bargaining position dalam berjalannya kerjasama. Hal tersebutlah yang seharusnya menjadi tugas dan tanggung jawab pemangku kepentingan yang lain untuk meningkatkan peran serta masyarakat dalam kerjasama. Namun hal tersebut juga perlu dibarengi dengan adanya kemauan dan stereotip positif masyarakat terhadap kerjasama yang terjalin.

Upaya-upaya peningkatan peran masyarakat tentunya berpengaruh bagi proses replikasi kelompok. Berdasarkan kondisi di lapangan, kelompok tabungan perumahan tidak mengalami perkembangan dan pertambahan anggota secara signifikan. Implikasinya juga terhadap proses replikasi kelompok, baik internal maupun eksternal terhambat, bahkan belum dapat dilaksanakan. Penyebabnya adalah rendahnya peran masyarakat dalam kerjasama dan kurangnya perhatian pemangku kepentingan yang penting dan berpengaruh dalam kerjasama. Oleh karena itu, penting untuk menumbuhkan pengertian bahwa masyarakat tidak hanya sebagai obyek dalam kerjasama, tapi juga berperan sebagai subyek penting dan pengaruh dalam kerjasama ini. Hal tersebut akan berdampak pada kesadaran dan peningkatan peran masyarakat dalam berjalannya kegiatan kelompok, sehingga dapat dilakukan proses replikasi, secara internal maupun eksternal kelompok.

Menurut Chifos (2007) dan Meneses (2005), peran pemangku kepentingan dalam pengembangan komunitas atau kelompok masyarakat meliputi regulasi, pemberdayaan, pendampingan dan penguatan. Keempat peran tersebut dapat dilakukan oleh semua pemangku kepentingan yang terlibat dalam kerjasama, yaitu pemerintah, masyarakat, Catur Pilar, dan dinas pendukung lainnya. Peran-peran tersebut dibutuhkan untuk menjaga 


\section{Peran Pemangku Kepentingan Dalam Pembentukan Komunitas Guna Mencapai Ketahanan Sosial Ekonomi}

berjalannya kerjasama dan keberlanjutan kelompok. Tindakan yang dapat dilakukan sesuai dengan keempat peran tersebut dapat dilihat pada tabel berikut.

Tabel 5. Peran Pemangku Kepentingan dalam Pengembangan Kelompok Tabungan Perumahan

\begin{tabular}{|c|c|c|c|}
\hline Peran & Pemerintah & Masyarakat & Lembaga Pendukung \\
\hline Regulasi & $\begin{array}{l}\text { - Kebijakan dan strategi } \\
\text { mengenai penanganan } \\
\text { bencana dan dampak } \\
\text { perubahan iklim } \\
\text { - Kebijakan dan peraturan } \\
\text { mengenai pola } \\
\text { penanggulangan kemiskinan }\end{array}$ & & \\
\hline Pemberdayaan & $\begin{array}{l}\text { - Sosialisasi program-program } \\
\text { - Inisiasi program ke } \\
\text { masyarakat }\end{array}$ & $\begin{array}{l}\text { - Turut serta dan aktif dalam } \\
\text { kegiatan kelompok } \\
\text { - Sosialisai dan penularan } \\
\text { melalui kegiatan di } \\
\text { komunitas yang terbentuk } \\
\end{array}$ & $\begin{array}{l}\text { - Sosialisasi manajemen } \\
\text { kegiatan pengembangan } \\
\text { komunitas }\end{array}$ \\
\hline Pendampingan & - Pelatihan dan pembinaan & $\begin{array}{l}\text { - Penjaringan anggota } \\
\text { komunitas } \\
\text { - Pembentukan kelompok- } \\
\text { kelompok tabungan } \\
\text { perumahan di tingkat RT }\end{array}$ & $\begin{array}{l}\text { - Penyediaan tenaga ahli } \\
\text { dan fasilitator }\end{array}$ \\
\hline Penguatan & $\begin{array}{l}\text { - Pembangunan kerjasama } \\
\text { dengan pemangku } \\
\text { kepentingan lain } \\
\text { - Dukungan terhadap } \\
\text { komunitas dengan } \\
\text { memfasilitasi kebutuhan } \\
\text { dasar komunitas } \\
\text { - Bantuan modal (finansial) } \\
\text { - Penyuluhan }\end{array}$ & $\begin{array}{l}\text { - Kerjasama dengan catur } \\
\text { pilar dan lembaga lain } \\
\text { - Penyusunan rencana } \\
\text { kegiatan, aturan dan norma } \\
\text { yang berlaku } \\
\text { - Pelaksanaan kegiatan } \\
\text { setiap kelompok } \\
\text { masyarakat yang terbentuk }\end{array}$ & $\begin{array}{l}\text { - Penjalinan kerjasama } \\
\text { dengan pemerintah dan } \\
\text { masyarakat } \\
\text { - Bantuan modal } \\
\text { (finansial) } \\
\text { - Mendorong peningkatan } \\
\text { keterlibatan masyarakat } \\
\text { dalam kerjasama }\end{array}$ \\
\hline
\end{tabular}

Sesuai dengan kondisi di lapangan, masing-masing pemangku kepentingan tersebut tentunya tidak semua dapat menjalankan peran yang optimal dan sesuai dengan kepentingannya dalam kerjasama. Jika merujuk pada empat peran pemangku kepentingan dalam pengembangan komunitas menurut Chifos dan Meneses, pemangku kepentingan yang terlibat dalam kerjasama ini tidak menjalankan perannya sesuai dengan tugas dan tanggung jawab yang diemban. Disfungsi peran akan menimbulkan dampak terhadap berjalannya kerjasama. Dampak tersebut pada umumnya akan membawa implikasi negatif terhadap kerjasama, khususnya keberlangsungan kelompok tabungan perumahan. Konsekuensi terjadinya disfungsi peran pemangku kepentingan dapat dilihat pada Tabel 6.

Pemerintah mempunyai pengaruh dan kepentingan yang sangat besar dalam kerjasama yang diwujudkan dalam pengembangan kelompok tabungan perumahan. Hal tersebut dikarenakan pemerintah merupakan inisiator kegiatan tabungan perumahan. Kegiatan tabungan perumahan ini merupakan bagian dari rencana program pemerintah yang sudah disusun dan diatur, sehingga masyarakat dan pemangku kepentingan lain tinggal mengikuti apa yang ada dan berusaha untuk melanjutkan serta mengembangkan kerjasama secara mandiri. Adapun masyarakat hingga saat ini hanya menganggap perannya sebatas obyek penerima manfaat dalam kerjasama yang dijalin. Hal tersebut berimplikasi pada kurangnya keaktifan dan kesadaran masyarakat untuk mengembangkan 
diri. Terlihat pada sebagian besar masyarakat yang merupakan anggota kelompok tabungan perumahan masih bergantung pada keaktifan penggerak (Bu Nardi) dalam memobilisasi kegiatan kelompok.

Tabel 6. Konsekuensi Disfungsi Peran Pemangku Kepentingan Terhadap Kerjasama

\begin{tabular}{|c|c|c|}
\hline $\begin{array}{c}\text { Pemangku } \\
\text { Kepentingan }\end{array}$ & Disfungsi Peran & Dampak \\
\hline Bapermas & $\begin{array}{l}\text { Tidak melakukan pembinaan dan } \\
\text { pendampingan secara intensif terhadap } \\
\text { pelaksanaan kegiatan tabungan perumahan } \\
\text { di RW } 7 \\
\text { Tetap berpandangan optimis tanpa melihat } \\
\text { kondisi riil di lapangan } \\
\text { Kurang aktif dalam melakukan channelling } \\
\text { dengan catur pilar dan dinas lain }\end{array}$ & $\begin{array}{l}\text { Kerjasama kelompok tabungan } \\
\text { perumahan ini stagnan } \\
\text { Tidak bertambahnya anggota dan } \\
\text { pembentukan kelompok tabungan } \\
\text { perumahan lain. }\end{array}$ \\
\hline Masyarakat & $\begin{array}{l}\text { Menganggap hanya sebagai obyek dalam } \\
\text { berjalannya kerjasama } \\
\text { Tidak mengemukakan aspirasi secara aktif } \\
\text { Kurang berupaya untuk menghidupkan } \\
\text { kegiatan kelompok }\end{array}$ & $\begin{array}{l}\text { Tidak ada dukungan terhadap } \\
\text { penggerak seperti Bu Nardi } \\
>\text { Tidak muncul bibit championship lain } \\
\text { (selain Bu Nardi) } \\
>\text { Gagal replikasi internal maupun } \\
\text { eksternal }\end{array}$ \\
\hline $\begin{array}{l}\text { Catur Pilar } \\
\text { (PKK, } \\
\text { BKM,LPM, } \\
\text { Kelurahan) }\end{array}$ & $\begin{array}{l}\text { Tidak berupaya terlibat langsung dalam } \\
\text { kerjasama } \\
\text { Hanya menjadi penonton berjalannya } \\
\text { kerjasama dalam kegiatan tabungan } \\
\text { perumahan }\end{array}$ & $\begin{array}{l}\text { Tidak tercipta hubungan kerjasama } \\
\text { secara langsung dengan catur pilar, } \\
\text { kecuali PKK } \\
\text { Kelompok merasa bukan bagian dari } \\
\text { naungan catur pilar }\end{array}$ \\
\hline $\begin{array}{l}\text { Dinas-dinas } \\
\text { Pendukung }\end{array}$ & $\begin{array}{l}\text { Tidak berperan aktif untuk ikut serta dalam } \\
\text { kerjasama }\end{array}$ & $\begin{array}{l}\text { Kurangnya pendampingan dalam } \\
\text { teknis pelaksanaan } \\
\text { tidak bertambah pengetahuan } \\
\text { kelompok mengenai upaya } \\
\text { mempertahankan eksistensi (mendapat } \\
\text { sumber dana tambahan untuk nabung) }\end{array}$ \\
\hline
\end{tabular}

Jika dilihat secara keseluruhan, masing-masing pemangku kepentingan belum melakukan perannya secara optimal. Banyak ditemukan disfungsi peran yang dilakukan oleh beberapa pemangku kepentingan. Hal ini membawa implikasi negatif terhadap kerjasama yang terjalin. Diantaranya bagi kegiatan kelompok dan semangat untuk terus menggerakan partisipasi masyarakat dalam kerjasama. Mekanisme kerjasama yang terjalin dalam upaya pengembangan kelompok menjadi stagnan.

Pada dasarnya, Mekanisme kerjasama yang terjalin dalam kelompok tabungan perumahan merupakan peluang dalam pembentukan ketahanan sosial ekonomi masyarakat. Peluang tersebut dapat terbuka apabila mekanisme kerjasama yang terjalin sinergi dan berkelanjutan melalui pengoptimalan peran pemangku kepentingan. Pada kenyataannya, mekanisme yang telah terbentuk dalam kurun waktu satu tahun ini berjalan stagnan. Hal tersebut tentunya akan berimplikasi langsung terhadap keberlanjutan kelompok tabungan perumahan. Yang pada hakikatnya, tujuan dan manfaat kegiatan tabungan perumahan ini akan menghasilkan outcome peningkatan kemandirian masyarakat yang berpengaruh terhadap keberdayaan masyarakat dalam meningkatkan ketahanan ekonomi dan sosial mereka dalam kondisi rentan. Mekanisme yang demikian dapat melemahkan ketahanan sosial ekonomi masyarakat Panjang Baru yang sedang dibangun untuk menghadapi kondisi rentan kemiskinan, banjir dan rob. Berikut ini 
merupakan rangkaian sintesis peran pemangku kepentingan hingga implikasinya terhadap kerjasama pengembangan kelompok.

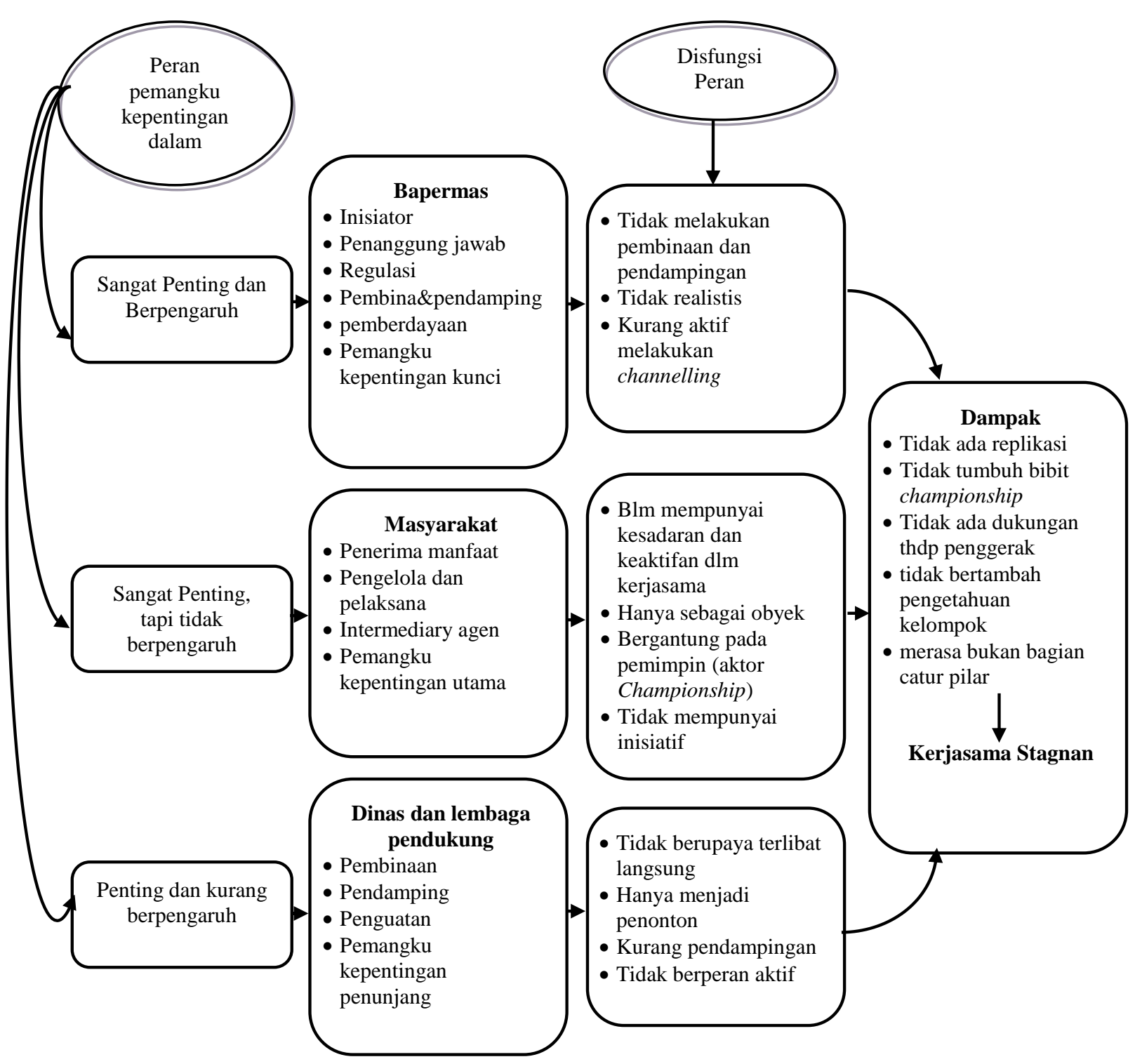

Gambar 8. Sintesis Peran Pemangku Kepentingan dalam Kerjasama

\section{Kesimpulan}

Dalam upaya pengembangan kelompok tabungan perumahan guna mencapai ketahanan sosial ekonomi masyarakat di Kelurahan Panjang Baru, yang sangat penting adalah peran pemangku kepentingan. Peran pemangku kepentingan mempunyai pengaruh besar dalam proses pembentukan dan pengembangan kelompok. Pada kenyataannya, pemangku kepentingan yang terlibat melakukan disfungsi peran dalam mekanisme kerjasama pengembangan kelompok tersebut. Disfungsi peran yang dilakukan antara lain adalah tidak melakukan pembinaan lebih lanjut (Bapermas), bergantung pada pemimpin (masyarakat), 
kurang berperan aktif (dinas pendukung). Hal tersebut membawa dampak negatif yang pada akhirnya kerjasama dalam pengembangan kelompok menjadi stagnan. implikasi lebih jauh dari kerjasama yang stagnan adalah melemahkan ketahanan sosial ekonomi masyarakat yang sedang berusaha untuk dicapai.

Pembelajaran yang dapat diambil adalah:

- Pentingnya peran inisiator dan intermediary agent dalam menginisiasi masyarakat secara berkelompok.

- Sikap championship dari masyarakat sangat menunjang bagi keberhasilan pembentukan kelompok dan memobilisasi partisipasi masyarakat dalam kerjasama.

- Perlunya proses replikasi untuk menunjang keberlangsungan dan keberlanjutan kelompok di wilayah lain sehingga dapat dirasakan manfaat kerjasama secara luas.

- Pembinaan, pendampingan, dan monitoring dan evaluasi harus dilakukan dalam mekanisme kerjasama pengembangan kelompok.

\section{Ucapan Terima Kasih}

Terimakasih kepada Ibu Ir. Artiningsih, Msi selaku pembimbing penelitian ini serta kepada responden di Kelurahan Panjang Baru khususnya yang telah bersedia menjadi sumber informasi.

\section{Daftar Pustaka}

Adiyoso, Wignyo. 2009. Menggugat Perencanaan Partisipatif dalam Pemberdayaan Masyarakat. Surabaya: CV Putra Media Nusantara.

Bapermas KB. 2010. Buletin TPKP. Pekalongan: Kabid Penanggulangan Kemiskinan Bapermas KB Kota Pekalongan.

Bapermas KB. 2010. Dokumen Pola Penanggulangan Kemiskinan Kota Pekalongan. Pekalongan: Kabid Penanggulangan Kemiskinan Bapermas KB Kota Pekalongan.

Bulu, Yohanes G. dkk. 2009. "Pengaruh Modal Sosial dan Keterdedahan Informasi Inovasi terhadap Tingkat Adopsi Inovasi Jagung di Kabupaten Lombok Timur Nusa Tenggara Barat.” Jurnal Agro Ekonomi. Vol. 27 (1), pp 1-21. http://pse.litbang.deptan.go.id/ind/pdffiles/JAE\%2027-1a.pdf. Diakses pada tanggal 17 November 2010.

Bungin, Burhan. 2007. Penelitian Kuantitatif. Jakarta: PT. Rajagrafindo Persada.

Crosby, B.L. 1992. Stakeholder Analysis: A vital tool for strategic managers. Technical Notes, No. 2. Agency for International Development, Washington DC.

Fajber, Liz. 2009. Approaching vulnerability assessments in ACCCRN cities: Information on methods for the Indonesia team. ISET.

Iqbal, Muhammad. 2007. "Analisis Pemangku Kepentingan dan Implementasinya dalam Pembangunan Pertanian”. Jurnal Litbang Pertanian, Vol. 26 (3), pp 89-99.

Race, D. and J. Millar. 2006. Training Manual: Social and community dimensions of ACIAR Projects. Australian Center for International Agricultural Research - Institute for Land, Water, and Society of Charles Sturt University, Australia.

Soekanto, Soerjono. 2010. Sosiologi Suatu Pengantar. Jakarta: Rajawali Pers.

Soetomo. 2006. Strategi-strategi Pembangunan Masyarakat. Yogyakarta: Pustaka Pelajar.

Walgito, Bimo. 2003. Psikologi Sosial Suatu Pengantar. Yogyakarta: CV. Andi Offset

Wea, Maria Carolina J.P. 2009. “Keberlanjutan Pengelolaan Lingkungan Melalui Pembentukan Komunitas Berkelanjutan: Belajar dari Keberhasilan Gerakan Hijau dan Bersih Komunitas Banjarsari." Tugas Akhir tidak diterbitkan, Program Studi Perencanaan Wilayah dan Kota, Fakultas Teknik Universitas Diponegoro, Semarang 
48 Peran Pemangku Kepentingan Dalam Pembentukan Komunitas Guna Mencapai Ketahanan Sosial Ekonomi

JURNAL WILAYAH DAN LINGKUNGAN, 1 (1), 33-48 